\title{
Colwellia asteriadis sp. nov., a marine bacterium isolated from the starfish Asterias amurensis
}

Correspondence
Hak Cheol Kwon
hkwon@kist.re.kr

\author{
Eun Ju Choi, ${ }^{1,2}$ Hak Cheol Kwon, ${ }^{1}$ Hye Yeon Koh, ${ }^{2}+$ Young Sug Kim ${ }^{3}$ \\ and Hyun Ok Yang ${ }^{1}$
}
${ }^{1}$ Korea Institute of Science and Technology, Gangneung Institute, 290 Daejeon-dong, Gangneung, Gangon-do 210-340, Republic of Korea
${ }^{2}$ Division of Applied Marine Biotechnology and Engineering, Faculty of Marine Bioscience and Technology, Gangneung-Wonju National University, Gangneung 210-702, Republic of Korea
${ }^{3}$ East Sea Fisheries Research Institute, 30-6 Dongdeok-ri, Yeongok-myeon, Gangneung 210-861, Republic of Korea

\begin{abstract}
A marine bacterial strain, $\mathrm{KMD} 002^{\top}$, was isolated from an Amur starfish, Asterias amurensis,

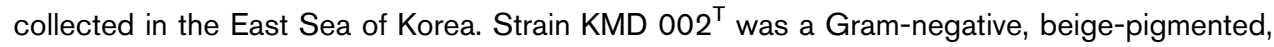
rod-shaped bacterium. The strain was capable of growth at relatively low temperatures $\left(4-25{ }^{\circ} \mathrm{C}\right)$ and over a broad $\mathrm{pH}$ range $(\mathrm{pH} 4.0-10.0)$. The major fatty acids were $\mathrm{C}_{16: 1} \omega 7 \mathrm{c}$ and/or iso$\mathrm{C}_{15: 0} 2-\mathrm{OH}$ and $\mathrm{C}_{16: 0}$ and the predominant isoprenoid quinone was $\mathrm{Q}-8$. The DNA G+C content of strain KMD $002^{\top}$ was 40.3 mol\%. Phylogenetic analysis using $16 \mathrm{~S}$ rRNA gene

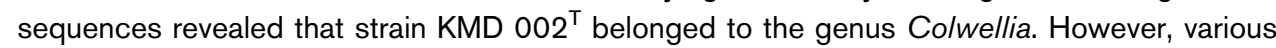
phenotypic properties as well as low 16S rRNA gene sequence similarities to members of the genus Colwellia (94.1-96.7\%) suggested that strain $\mathrm{KMD}_{00} 2^{\top}$ is a representative of a novel species, for which the name Colwellia asteriadis sp. nov. is proposed. The type strain is KMD $002^{\top}\left(=\right.$ KCCM $90077^{\top}=$ JCM $\left.15608^{\top}\right)$.
\end{abstract}

A culture-dependent investigation of the microbial diversity associated with marine creatures led to the isolation of 18 culturable bacterial strains from a specimen of the Amur starfish, Asterias amurensis, collected from the Korean East Sea. The investigation of these strains led to the identification of the new genus and species Kistimonas asteriae (type strain KMD 001 $1^{\mathrm{T}}$; Choi et al., 2010) and strain KMD 002, belonging to the class Gammaproteobacteria. Phylogenetic analysis of the 16S rRNA gene sequence of strain KMD 002 revealed a close affinity with the genus Colwellia. Members of Colwellia are psychrophiles and facultative anaerobes belonging to the order Alteromonadales and the family Colwelliaceae (Ivanova et al., 2004). At the time of writing, the genus Colwellia included 10 species, Colwellia psychrerythraea, C. hadaliensis (Deming et al., 1988), C. demingiae, C. hornerae, C. psychrotropica, C. rossensis (Bowman et al., 1998), C. maris (Yumoto et al., 1998), C. piezophila (Nogi et al., 2004), C. aestuarii (Jung et al., 2006) and C. polaris (Zhang et al., 2008).

tPresent address: Korea Polar Research Institute, KORDI, Incheon 406840, Republic of Korea.

The GenBank/EMBL/DDBJ accession number for the 16S rRNA gene sequence of strain $\mathrm{KMD} 002^{\top}$ is EU599214.


online version of this paper.
Strain KMD $002^{\mathrm{T}}$ was isolated from the skin of an $A$. amurensis specimen, which was collected at a depth of $10 \mathrm{~m}$ near the Im-Won port in Korea in April 2007. The skin was macerated and mixed with seawater $(1: 10)$ and an aliquot $(100 \mu \mathrm{l})$ of the suspension was spread on A1 agar, a seawater-based medium [containing (per litre filtered seawater) $10.0 \mathrm{~g}$ starch (Difco), $4.0 \mathrm{~g}$ peptone (Difco), $2.0 \mathrm{~g}$ yeast extract (Bacto) and $18.0 \mathrm{~g}$ agar (Junsei)]. After incubation at $25{ }^{\circ} \mathrm{C}$ for 2 weeks, single colonies were selected and subcultured on Al agar to achieve purity. Stocks of each strain were generated by incubation in $\mathrm{A} 1$ broth $(25 \mathrm{ml})$ at $25{ }^{\circ} \mathrm{C}$ for 7 days and stored at $-80{ }^{\circ} \mathrm{C}$ in A1 broth containing $15 \%$ glycerol.

For morphological study, strain $\mathrm{KMD} 002^{\mathrm{T}}$ was cultured at $20{ }^{\circ} \mathrm{C}$ for 7 days on $\mathrm{A} 1$ agar and marine agar (MA; Difco). Cell morphology was observed using scanning electron microscopy (S-3500N; Hitachi). Cell motility was examined using light microscopy (Eclipse TE2000 U; Nikon) and the presence of flagella was determined using transmission electron microscopy (CM 20; Philips) using sections cut with a Reichert Ultracut E (Leica).

Growth of strain KMD $002^{\mathrm{T}}$ at 4, 10, 15, 20, 25, 30, 37 and $42{ }^{\circ} \mathrm{C}$ was examined on A1 agar and MA and in A1 broth and at 4,10 and $25{ }^{\circ} \mathrm{C}$ on nutrient agar (Difco) and tryptic soy broth agar (TSA; Bacto). The requirement for and 
tolerance of $\mathrm{NaCl}$ was examined on $\mathrm{Al}$ agar containing 0 $15 \%(\mathrm{w} / \mathrm{v}) \mathrm{NaCl}$ (in increments of $1 \%$ ). Growth at $\mathrm{pH} 4$ 10 (in increments of $1 \mathrm{pH}$ unit) was tested in A1 broth after adjustment of the $\mathrm{pH}$. Gram staining was performed according to the method described by Süßmuth et al. (1987). Anaerobic growth was evaluated on Al agar and MA in an anaerobic system (Glove Box; Three-Shine). Hydrolysis of starch, casein, gelatin and Tween 80 was tested using A1 medium as described by Smibert \& Krieg (1994). Chitin hydrolysis was tested on chitin agar as described by Hsu \& Lockwood (1975). Catalase activity was determined according to Nogi \& Kato (1999). Utilization of carbon sources was investigated using the API $50 \mathrm{CH}$ system (bioMérieux) according to the manufacturer's recommendations. The API 20E, API 20NE and API ZYM systems (bioMérieux) were used to determine additional biochemical properties.

Fatty acid methyl esters were extracted and prepared according to the standard protocol of the Sherlock Microbial Identification System (Sasser, 1990). The DNA $\mathrm{G}+\mathrm{C}$ content was determined by HPLC as described by Martin et al. (1997). Isoprenoid quinones were extracted according to the method described by Bligh \& Dyer (1959) and separated by HPLC as described by Collins \& Jones (1981).

Chromosomal DNA of strain KMD $002^{\mathrm{T}}$ was isolated using the G-spin genomic DNA extraction kit (iNtRON Biotechnology). The $16 \mathrm{~S}$ rRNA gene was amplified by PCR using the universal primers $27 \mathrm{f}$ and $1492 \mathrm{r}$, which anneal to positions 8-27 and 1492-1513, respectively (Escherichia coli numbering; Brosius et al., 1978). $16 \mathrm{~S}$ rRNA gene sequence similarities were determined by performing BLAST searches of public databases (Altschul et al., 1990). A multiple sequence alignment of representative sequences was performed using CLUSTAL $\mathrm{W}$ version 1.8 (Thompson et al., 1994). A neighbour-joining analysis (Kimura, 1980) and a bootstrap analysis of 1000 data resamplings were performed to determine the robustness of the topology. A phylogenetic tree was reconstructed using MEGA version 4 (Tamura et al., 2007).

Strain KMD $002^{\mathrm{T}}$ was a Gram-negative, facultatively anaerobic, beige-pigmented bacterium after incubation at $20{ }^{\circ} \mathrm{C}$ on A1 agar and MA. The strain was motile with a single polar flagellum (Fig. 1). Scanning electron microscope observations of strain KMD $002^{\mathrm{T}}$ revealed short rodshaped cells, $0.4-0.5 \mu \mathrm{m}$ in diameter and $0.7-1.0 \mu \mathrm{m}$ long (Supplementary Fig. S1, available in IJSEM Online). Strain KMD $002^{\mathrm{T}}$ grew at $4-25{ }^{\circ} \mathrm{C}$ (optimum $15{ }^{\circ} \mathrm{C}$ ) on A1 agar and MA and in A1 broth. Strain KMD $002^{\mathrm{T}}$ grew on TSA at 4 and $25{ }^{\circ} \mathrm{C}$ and on nutrient agar at 15 and $25{ }^{\circ} \mathrm{C}$. In general, members of the genus Colwellia are psychrophilic bacteria that have optimal growth at $\leqslant 20{ }^{\circ} \mathrm{C}$ and no growth over $30{ }^{\circ} \mathrm{C}$ (Bowman et al., 1998; Zhang et al., 2008; Jung et al., 2006). Strain KMD $002^{\mathrm{T}}$ grew with 0 $11 \%(\mathrm{w} / \mathrm{v}) \mathrm{NaCl}$, but not with $12-15 \%(\mathrm{w} / \mathrm{v}) \mathrm{NaCl}$, and at pH 4-10. With the API ZYM gallery, the phenotypic

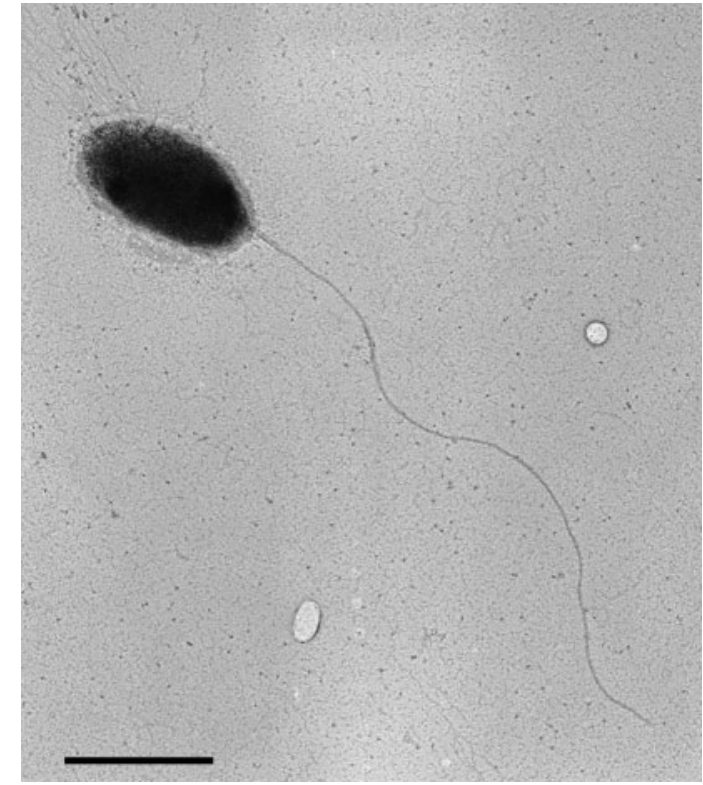

Fig. 1. Transmission electron micrograph of a cell of strain KMD $002^{\top}$ after growth on $\mathrm{A} 1$ medium at $20^{\circ} \mathrm{C}$ for 4 days.

profile of strain KMD $002^{\mathrm{T}}$ was similar to that of $C$. aestuarii SMK- $10^{\mathrm{T}}$ (Jung et al., 2006) except that $N$-acetyl$\beta$-glucosaminidase activity was detected and $\beta$-glucosidase was not detected in strain KMD $002^{\mathrm{T}}$. The cellular fatty acid profile of strain KMD $002^{\mathrm{T}}$ is presented in Table 1 together with those of other Colwellia species (Jung et al., 2006). The predominant fatty acids of strain KMD $002^{\mathrm{T}}$ were $\mathrm{C}_{16: 1} \omega 7 c$ and/or iso- $\mathrm{C}_{15: 0} 2-\mathrm{OH}$ and $\mathrm{C}_{16: 0}$. The characteristics of strain KMD $002^{\mathrm{T}}$ were similar to those reported for the genus Colwellia in previous studies (Yumoto et al., 1998), i.e. marine habitat, sodium ion requirement for good growth, non-fermentation of glucose, anaerobic respiration and major isoprenoid quinone Q-8.

The 16S rRNA gene sequence from strain KMD $002^{\mathrm{T}}$ clustered with those from strains of nine Colwellia species (Fig. 2) and shared 94.1-96.7\% similarity with these sequences. In particular, the $16 \mathrm{~S}$ rRNA gene sequence of strain $\mathrm{KMD} 002^{\mathrm{T}}$ showed 96.6 and $96.7 \%$ similarity to sequences from $C$. demingiae ACAM $459^{\mathrm{T}}$ and $C$. psychrerythraea ATCC $27364^{\mathrm{T}}$, respectively. However, strain $\mathrm{KMD} 002^{\mathrm{T}}$ is significantly distinguishable from these phylogenetic neighbours by utilization of aesculin, casein and D-fructose, colony colour and ability to grow at $25{ }^{\circ} \mathrm{C}$ on MA (Table 2). Even though we did not carry out DNA-DNA hybridization experiments, the phylogenetic and phenotypic distinctiveness of strain $\mathrm{KMD} 002^{\mathrm{T}}$ is sufficient to separate it from other recognized Colwellia species (Stackebrandt \& Goebel, 1994). In addition, strain KMD $002^{\mathrm{T}}$ showed similar physiological and chemotaxonomic characteristics to those of other genera such as 


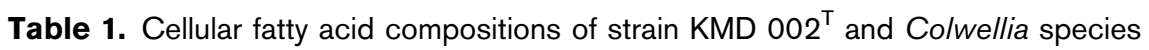

Strains: 1, Colwellia asteriadis sp. nov. KMD 002 ${ }^{\mathrm{T}}$; 2, C. psychrerythraea (four strains) (data from Bowman et al., 1998); 3, C. demingiae (two strains) (Bowman et al., 1998); 4, C. aestuarii SMK-10 ${ }^{\mathrm{T}}$ (Jung et al., 2006); 5, C. polaris $537^{\mathrm{T}}$ (Zhang et al., 2008); 6, C. hornerae ACAM 607 ${ }^{\mathrm{T}}$ (Bowman et al., 1998); 7, C. piezophila (two strains) (Nogi et al., 2004); 8, C. maris JCM 10085 ${ }^{\mathrm{T}}$ (Nogi et al., 2004); 9, C. psychrotropica ACAM 179 ${ }^{\mathrm{T}}$ (Bowman et al., 1998); 10, C. rossensis ACAM $608^{\mathrm{T}}$ (Bowman et al., 1998). Values are percentages of total fatty acids; fatty acids that represented $<0.1 \%$ of total content in all strains are not shown. tr, Trace $(\leqslant 0.1 \%$ of total content $) ;-$, not detected/not reported.

\begin{tabular}{|c|c|c|c|c|c|c|c|c|c|c|}
\hline Fatty acid & 1 & 2 & 3 & 4 & 5 & 6 & 7 & 8 & 9 & 10 \\
\hline \multicolumn{11}{|l|}{ Straight-chain } \\
\hline $\mathrm{C}_{10: 0}$ & 1.3 & - & - & 1.7 & 2.3 & - & - & - & - & - \\
\hline $\mathrm{C}_{11: 0}$ & 0.5 & - & - & - & 1.2 & - & - & - & - & - \\
\hline$C_{12: 0}$ & 3.2 & - & - & 0.5 & $\operatorname{tr}$ & - & $1-2$ & 2 & - & - \\
\hline $\mathrm{C}_{13: 0}$ & 0.2 & - & - & - & - & - & - & - & - & - \\
\hline $\mathrm{C}_{14: 0}$ & 2 & $5.1-7.8$ & $7.6-8.0$ & 2.3 & 1.5 & 3 & 9 & - & 0.8 & 4.6 \\
\hline $\mathrm{C}_{15: 0}$ & 4 & $1.7-11.0$ & $0.9-1.4$ & 4.8 & - & 2.9 & 3 & 4 & 2.7 & 2.9 \\
\hline$C_{16: 0}$ & 27.3 & $26.8-33.2$ & $21.9-23.6$ & 9.9 & 7.6 & 13.5 & $31-33$ & 25 & 21.9 & 27.1 \\
\hline$C_{17: 0}$ & 1.7 & $0-1.3$ & $\operatorname{tr}$ & 2.5 & 2.1 & - & - & 3 & 1.5 & 0.1 \\
\hline $\mathrm{C}_{18: 0}$ & 0.9 & $0.1-2.4$ & $0.2-0.5$ & - & $\operatorname{tr}$ & 2 & - & - & 0.4 & $\operatorname{tr}$ \\
\hline \multicolumn{11}{|l|}{ Branched } \\
\hline iso- $\mathrm{C}_{16: 0}$ & 0.7 & $0-0.2$ & - & 10.4 & 5.7 & 10.3 & - & - & - & - \\
\hline \multicolumn{11}{|l|}{ Unsaturated } \\
\hline $\mathrm{C}_{14: 1^{*}}$ & - & $5.1-7.3$ & $9.1-9.3$ & - & - & 2.8 & 2 & 2 & 2 & 2.8 \\
\hline$C_{15: 1}$ & - & $0-2.7$ & $1.9-2.6$ & 10.9 & 17.6 & 21.4 & 3 & 6 & 4.3 & 4.1 \\
\hline $\mathrm{C}_{15: 1} \omega 8 c$ & 3.0 & - & - & - & - & - & - & - & - & - \\
\hline $\mathrm{C}_{15: 1} \omega 6 c$ & 0.2 & - & - & - & - & - & - & - & - & - \\
\hline $\mathrm{C}_{16: 1} \dagger$ & - & $31.4-36.3$ & $37.5-37.8$ & - & - & 15.4 & $48-50$ & 51 & 56.8 & 43.4 \\
\hline $\mathrm{C}_{16: 1} \omega 9 c$ & 4.1 & $6.2-8.8$ & $9.5-11.8$ & 5.6 & 3.9 & 2.0 & - & - & - & 1.8 \\
\hline $\mathrm{C}_{17: 1}$ & - & $0-2.2$ & $\operatorname{tr}$ & 11.8 & 13.7 & 7.5 & - & 4 & 5.4 & 0.5 \\
\hline $\mathrm{C}_{17: 1} \omega 8 c$ & 3.9 & - & - & - & - & - & - & - & - & - \\
\hline $\mathrm{C}_{18: 1} \omega 9 c$ & 0.6 & $0-1.7$ & $\operatorname{tr}-0.2$ & 0.6 & $\operatorname{tr}$ & 1.4 & - & - & 0.3 & 0.8 \\
\hline $\mathrm{C}_{18: 1} \omega 7 c$ & 1.8 & $0.3-2.1$ & $1.3-1.4$ & 1.2 & - & - & - & - & 1.9 & 4.2 \\
\hline $\mathrm{C}_{20: 5} \omega 3 c$ & - & $0-1.5$ & - & - & - & - & - & - & 0.1 & $\operatorname{tr} \dagger$ \\
\hline $\mathrm{C}_{22: 6} \omega 3 \mathrm{c}$ & - & $5.5-8.0$ & $1.7-2.2$ & - & - & 2.1 & - & - & 0.7 & 6 \\
\hline \multicolumn{11}{|l|}{ Hydroxy } \\
\hline $\mathrm{C}_{10: 0} 3-\mathrm{OH}$ & 0.5 & - & - & 0.5 & - & - & - & - & - & - \\
\hline $\mathrm{C}_{11: 0} 3-\mathrm{OH}$ & 0.8 & - & - & 2.6 & 4.8 & - & - & - & - & - \\
\hline $\mathrm{C}_{12: 0} 3-\mathrm{OH}$ & 4.2 & - & - & 2.5 & 3.1 & - & $0-1$ & 3 & - & - \\
\hline $\mathrm{C}_{12: 1} 3-\mathrm{OH}$ & 0.1 & - & - & - & - & - & - & - & - & - \\
\hline iso- $\mathrm{C}_{12: 0} 3-\mathrm{OH}$ & - & - & - & 5.3 & 6.5 & - & - & - & - & - \\
\hline $\mathrm{C}_{16: 0} 3-\mathrm{OH}$ & 0.7 & - & - & - & - & - & - & - & - & - \\
\hline \multicolumn{11}{|l|}{ Summed features $\ddagger$} \\
\hline $\mathrm{C}_{16: 1} \omega 7 c$ and/or iso- $\mathrm{C}_{15: 0} 2-\mathrm{OH}$ & 36.5 & - & - & 23.6 & 23.0 & - & - & - & - & - \\
\hline $\mathrm{C}_{13: 0} 3-\mathrm{OH}$ and/or iso- $\mathrm{C}_{15: 1}$ & 0.4 & - & - & - & - & - & - & - & - & - \\
\hline $\mathrm{C}_{14: 0} 3-\mathrm{OH}$ and/or iso- $\mathrm{C}_{16: 1}$ & 0.3 & - & - & - & - & - & - & - & - & - \\
\hline
\end{tabular}

${ }^{\star}$ Reported as $C_{14: 1} \omega 7 c$ by Bowman et al. (1998).

$\dagger$ Reported as $\mathrm{C}_{16: 1} \omega 7 \mathrm{c}$ by Bowman et al. (1998).

$¥$ Summed features represent two or three fatty acids that cannot be separated by the Microbial Identification System.

Alteromonas, Pseudoalteromonas and Shewanella (Yumoto et al., 1998). However, strain KMD $002^{\mathrm{T}}$ shared low $16 \mathrm{~S}$ rRNA gene sequence similarity $(<90.0 \%)$ with these genera and the phylogenetic tree showed that members of these genera were not closely related to strain KMD $002^{\mathrm{T}}$. Although strain KMD $002^{\mathrm{T}}$ was also closely related to type strains of species in the genus Thalassomonas (94.4-95.8\% $16 \mathrm{~S}$ rRNA gene sequence similarity), strain $\mathrm{KMD} 002^{\mathrm{T}}$ was distinct from the genus Thalassomonas in physiological and chemotaxonomic characters, i.e. growth at $4{ }^{\circ} \mathrm{C}$, nitrate reduction and enzyme activities (Yi et al., 2004).

On the basis of the phenotypic and phylogenetic data, it is proposed that strain $\mathrm{KMD} 002^{\mathrm{T}}$ represents a novel species of the genus Colwellia, for which the name Colwellia asteriadis sp. nov. is proposed. 


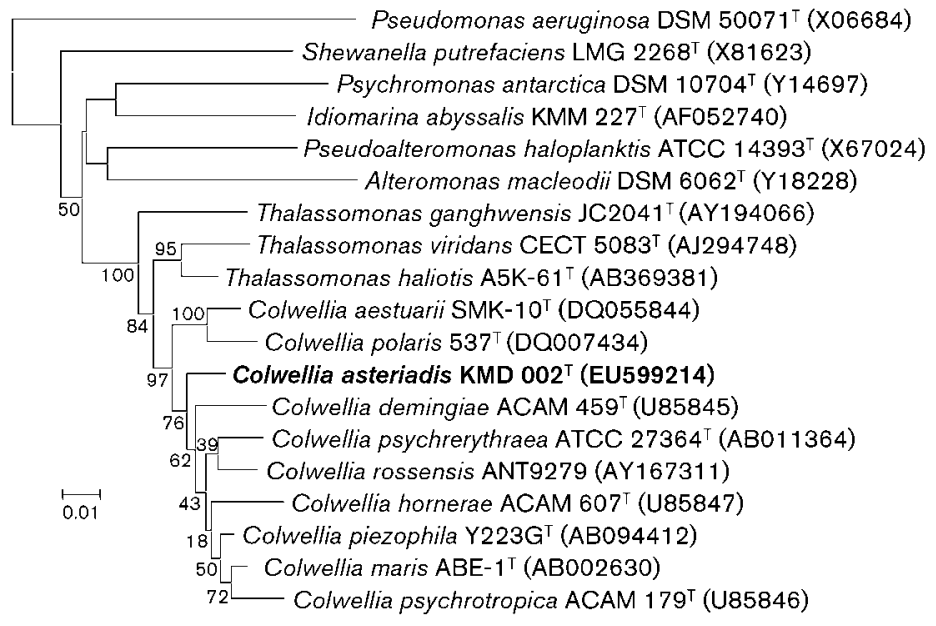

Fig. 2. Neighbour-joining phylogenetic tree based on 16S rRNA gene sequences showing the position of strain $\mathrm{KMD} 002^{\top}$ among strains of other Colwellia species and representing other genera. Bootstrap values based on 1000 resamplings are shown as percentages at branch nodes. Bar, 0.01 substitutions per nucleotide position.

Table 2. Differential phenotypic characteristics of strain $\mathrm{KMD}_{0} 02^{\top}$ and other Colwellia species

Strains: 1, C. asteriadis sp. nov. KMD 002 ${ }^{\mathrm{T}}$; 2, C. psychrerythraea (four strains) (data from Bowman et al., 1998; D’Aoust \& Kushner, 1972); 3, C. demingiae (two strains) (Bowman et al., 1998); 4, C. aestuarii SMK-10 ${ }^{\mathrm{T}}$ (Jung et al., 2006); 5, C. polaris 537 ${ }^{\mathrm{T}}$ (Zhang et al., 2008); 6, C. hornerae ACAM 607 (Bowman et al., 1998); 7, C. piezophila (two strains) (Nogi et al., 2004); 8, C. maris JCM 10085 ${ }^{\mathrm{T}}$ (Yumoto et al., 1998); 9, C. psychrotropica ACAM $179^{\mathrm{T}}$ (Bowman et al., 1998); 10, C. rossensis ACAM 608 ${ }^{\mathrm{T}}$ (Bowman et al., 1998). +, Positive; -, negative; v, variable (data in parentheses are for the type strain); ND, no data available, NG, no growth.

\begin{tabular}{|c|c|c|c|c|c|c|c|c|c|c|}
\hline Characteristic & 1 & 2 & 3 & 4 & 5 & 6 & 7 & 8 & 9 & 10 \\
\hline Cell shape ${ }^{\star}$ & $\mathrm{R}$ & $\mathrm{R}$ & $\mathrm{CR}$ & CR & $\mathrm{CR}$ & $\mathrm{CR}$ & $\mathrm{R}$ & $\mathrm{CR}$ & $\mathrm{CR}$ & $\mathrm{CR}$ \\
\hline Colony colour $\dagger$ & в & $\mathrm{R}$ & ow & GY & wH & ow & $\mathrm{ND}$ & $\mathrm{F}$ & ow & $\mathrm{CW}$ \\
\hline Growth at $25^{\circ} \mathrm{C}$ & + & - & - & + & + & - & - & - & + & - \\
\hline Urea & - & $\mathrm{v}(+)$ & - & - & - & - & $\mathrm{ND}$ & $\mathrm{ND}$ & + & + \\
\hline \multicolumn{11}{|l|}{ Hydrolysis of: } \\
\hline Casein & - & + & + & + & + & + & - & - & + & - \\
\hline Gelatin & - & $\mathrm{v}(+)$ & - & - & + & - & + & + & - & - \\
\hline Starch & + & + & + & - & + & + & - & - & - & + \\
\hline Tween 80 & - & + & - & + & + & + & ND & + & + & NG \\
\hline \multicolumn{11}{|l|}{ Utilization of: } \\
\hline L-Arabinose & - & - & - & + & + & - & - & - & - & + \\
\hline Cellobiose & - & - & - & + & - & - & - & ND & - & - \\
\hline Trehalose & - & - & - & + & $\mathrm{ND}$ & - & - & ND & - & - \\
\hline Acetate & + & + & + & - & + & + & ND & ND & + & + \\
\hline Citrate & - & - & + & - & - & + & ND & ND & - & + \\
\hline L-Malate & - & - & - & + & - & - & ND & ND & + & + \\
\hline \multicolumn{11}{|l|}{ Acid production from: } \\
\hline L-Arabinose, sucrose & - & - & - & + & - & - & - & - & - & - \\
\hline D-Fructose & - & - & - & + & - & - & - & - & - & - \\
\hline Lactose & - & - & - & + & - & - & - & ND & - & - \\
\hline D-Mannose & - & - & - & + & + & - & - & - & - & - \\
\hline Melibiose & - & - & - & + & + & - & ND & - & - & - \\
\hline
\end{tabular}

${ }^{\star} \mathrm{CR}$, Curved rod; $\mathrm{R}$, rod.

$\dagger \mathrm{B}$, Beige; CW, chalky white; F, flesh tint; GY, greyish yellow; OW, off white; R, red; wH, white. 


\section{Description of Colwellia asteriadis sp. nov.}

Colwellia asteriadis (as.te'ri.adis. N.L. n. Asterias a zoological genus name; N.L. gen. n. asteriadis of Asterias, referring to the isolation of the type strain from the starfish Asterias amurensis).

Cells are Gram-negative, facultatively anaerobic, motile rods $(0.4-0.5 \times 0.7-1.0 \mu \mathrm{m})$ with a single polar flagellum. Colonies are beige, circular, flat and smooth. Grows with $1-10 \%(\mathrm{w} / \mathrm{v}) \mathrm{NaCl}$ (weak without $\mathrm{NaCl}$ and no growth with $12-15 \% \mathrm{NaCl}$ ), at $4-25{ }^{\circ} \mathrm{C}$ (optimum $15{ }^{\circ} \mathrm{C}$ ) and at $\mathrm{pH}$ 4-10. Hydrolyses starch and chitin but not casein, Tween 80 or gelatin. Catalase-positive. Utilizes ribose, Dfructose, acetate, L-sorbose, starch, turanose, D-tagatose and potassium 5-ketogluconate, but not L-arabinose, Dgalactose, D-glucose, maltose, cellobiose, trehalose, citrate or L-malate. Reduces nitrates to nitrites and is positive for cytochrome $c$ oxidase. With API ZYM, alkaline phosphatase, esterase (C4), esterase lipase (C8), leucine arylamidase, acid phosphatase, naphthol-AS-BI-phosphohydrolase and $N$-acetyl- $\beta$-glucosaminidase are detected, but lipase (C14), valine arylamidase, cystine arylamidase, trypsin, $\alpha$ chymotrypsin, $\alpha$-galactosidase, $\beta$-galactosidase, $\beta$-glucuronidase, $\alpha$-glucosidase, $\beta$-glucosidase, $\alpha$-mannosidase and $\alpha$ fucosidase are not detected. The major cellular fatty acids are $\mathrm{C}_{16: 1} \omega 7 \mathrm{c}$ and/or iso- $\mathrm{C}_{15: 0} 2-\mathrm{OH}$ and $\mathrm{C}_{16: 0}$. The predominant ubiquinone is $\mathrm{Q}-8$. The DNA $\mathrm{G}+\mathrm{C}$ content of the type strain is $40.3 \mathrm{~mol} \%$.

The type strain, KMD $002^{\mathrm{T}}\left(=\mathrm{KCCM} 90077^{\mathrm{T}}=\mathrm{JCM}\right.$ $15608^{\mathrm{T}}$ ), was isolated from the skin of a specimen of the starfish Asterias amurensis collected at the Im-Won port in Samcheok on the East Sea of Korea.

\section{Acknowledgements}

This study was supported by the Korea Institute of Science and Technology institutional programme (grant numbers 2Z03100 and 2Z03270). We would like to thank D. J. Lee of 21C Submarine R\&D for collecting starfish specimens.

\section{References}

Altschul, S. F., Gish, W., Miller, W., Myers, E. W. \& Lipman, D. J. (1990). Basic local alignment search tool. J Mol Biol 215, 403-410.

Bligh, E. G. \& Dyer, W. J. (1959). A rapid method of total lipid extraction and purification. Can J Biochem Physiol 37, 911-917.

Bowman, J. P., Gosink, J. J., McCammon, S. A., Lewis, T. E., Nichols, D. S., Nichols, P. D., Skerratt, J. H., Staley, J. T. \& McMeekin, T. A. (1998). Colwellia demingiae sp. nov., Colwellia hornerae sp. nov., Colwellia rossensis sp. nov. and Colwellia psychrotropica sp. nov.: psychrophilic Antarctic species with the ability to synthesize

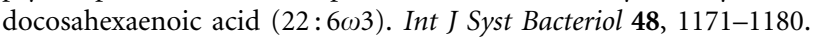

Brosius, J., Palmer, M. L., Kennedy, P. J. \& Noller, H. F. (1978). Complete nucleotide sequence of a $16 \mathrm{~S}$ ribosomal RNA gene from Escherichia coli. Proc Natl Acad Sci U S A 75, 4801-4805.

Choi, E. J., Kwon, H. C., Sohn, Y. C. \& Yang, H. O. (2010). Kistimonas asteriae gen. nov., sp. nov., a gammaproteobacterium isolated from Asterias amurensis. Int J Syst Evol Microbiol 60, 938-943.
Collins, M. D. \& Jones, D. J. (1981). A note on the separation of natural mixtures of bacterial ubiquinones using reverse-phase partition thin-layer chromatography and high performance liquid chromatography. J Appl Bacteriol 51, 129-134.

D’Aoust, J. Y. \& Kushner, D. J. (1972). Vibrio psychroerythrus sp. n.: classification of the psychrophilic marine bacterium, NRC 1004. J Bacteriol 111, 340-342.

Deming, J. W., Somers, L. K., Straube, W. L., Swartz, D. G. \& MacDonell, M. T. (1988). Isolation of an obligately barophilic bacterium and description of a new genus, Colwellia gen. nov. Syst Appl Microbiol 10, 152-160.

Hsu, S. C. \& Lockwood, J. L. (1975). Powdered chitin agar as a selective medium for enumeration of actinomycetes in water and soil. Appl Microbiol 29, 422-426.

Ivanova, E. P., Flavier, S. \& Christen, R. (2004). Phylogenetic relationships among marine Alteromonas-like proteobacteria: emended description of the family Alteromonadaceae and proposal of Pseudoalteromonadaceae fam. nov., Colwelliaceae fam. nov., Shewanellaceae fam. nov., Moritellaceae fam. nov., Ferrimonadaceae fam. nov., Idiomarinaceae fam. nov. and Psychromonadaceae fam. nov. Int J Syst Evol Microbiol 54, 1773-1788.

Jung, S. Y., Oh, T. K. \& Yoon, J. H. (2006). Colwellia aestuarii sp. nov., isolated from a tidal flat sediment in Korea. Int J Syst Evol Microbiol 56, 33-37.

Kimura, M. (1980). A simple method for estimating evolutionary rates of base substitutions through comparative studies of nucleotide sequences. J Mol Evol 16, 111-120.

Martin, K., Schumann, P., Rainey, F. A., Schuetze, B. \& Groth, I. (1997). Janibacter limosus gen. nov., sp. nov., a new actinomycete with meso-diaminopimelic acid in the cell wall. Int J Syst Bacteriol 47, 529534.

Nogi, Y. \& Kato, C. (1999). Taxonomic studies of extremely barophilic bacteria isolated from the Mariana Trench and description of Moritella yayanosii sp. nov., a new barophilic bacterial isolate. Extremophiles 3, 71-77.

Nogi, Y., Hosoya, S., Kato, C. \& Horikoshi, K. (2004). Colwellia piezophila sp. nov., a novel piezophilic species from deep-sea sediments of the Japan Trench. Int J Syst Evol Microbiol 54, 16271631.

Sasser, M. (1990). Identification of bacteria by gas chromatography of cellular fatty acids, MIDI Technical Note 101. Newark, DE: MIDI Inc.

Smibert, R. M. \& Krieg, N. R. (1994). Phenotypic characterization. In Methods for General and Molecular Bacteriology, pp. 607-654. Edited by P. Gerhardt, R. G. E. Murray, W. A. Wood \& N. R. Krieg. Washington, DC: American Society for Microbiology.

Stackebrandt, E. \& Goebel, B. M. (1994). Taxonomic note: a place for DNA-DNA reassociation and $16 \mathrm{~S}$ rRNA sequence analysis in the present species definition in bacteriology. Int J Syst Bacteriol 44, 846849.

Süßmuth, R., Eberspächer, J., Haag, R. \& Springer, W. (1987). Biochemisch-mikrobiologisches Praktikum. Stuttgart: Thieme (in German).

Tamura, K., Dudley, J., Nei, M. \& Kumar, S. (2007). MEGA4: molecular evolutionary genetics analysis (MEGA) software version 4.0. Mol Biol Evol 24, 1596-1599.

Thompson, J. D., Higgins, D. G. \& Gibson, T. J. (1994). CLUSTAL W: improving the sensitivity of progressive multiple sequence alignment through sequence weighting, position-specific gap penalties and weight matrix choice. Nucleic Acids Res 22, 4673-4680.

Yi, H., Bae, K. S. \& Chun, J. (2004). Thalassomonas ganghwensis sp. nov., isolated from tidal flat sediment. Int J Syst Evol Microbiol 54, 377-380. 
Yumoto, I., Kawasaki, K., Iwata, H., Matsuyama, H. \& Okuyama, H. (1998). Assignment of Vibrio sp. strain ABE-1 to Colwellia maris sp. nov., a new psychrophilic bacterium. Int J Syst Bacteriol 48, 13571362.
Zhang, D.-C., Yu, Y., Xin, Y.-H., Liu, H.-C., Zhou, P.-J. \& Zhou, Y.-G. (2008). Colwellia polaris sp. nov., a psychrotolerant bacterium isolated from Arctic sea ice. Int J Syst Evol Microbiol 58, 19311934. 